Unity Journal

Vol. III, 51-64, 2022

Doi: https://doi.org/10.3126/unityj.v3i01.43315

Prithvi Narayan Shah Research Center

Directorate General of Military Training, Nepali Army

Kathmandu, Nepal

\title{
Military Diplomacy as A Soft Power Strategy: Nepal-India Relations since 2015
}

\author{
Prem Prasad Limbu
}

\begin{abstract}
Military diplomacy has increasingly occupied a wider space in Nepal-India bilateral ties. It has been an effective soft power instrument to convey the message of an alive relationship, to bond the ties stronger and to revive the strained relationships. Today, it has got a central place as a political as well as a public concern. Such glorious history of military diplomacy begins after the challenging official visit of Chief of Army Staff (CoAS) of Nepal to India in 2016 and successful role to revive the severely ruined Nepal-India relationships by ending the unofficial blockade of India imposed to Nepal. Later, it has been recertified considering the Indian Army (IA) Chief's visit to Nepal in 2020 as an icebreaker visit to reset the soured bilateral relationship between two immediate neighbors developed after a bitter border row dispute in Kalapani-LipulekhLimpiyadhura area. These instances produce a new sequence, value and significance of military diplomacy in contemporary NepalIndia ties and raise a question:. Why and how is the military diplomacy as a soft power strategy is constructive and useful in diplomatic relation of the two democratic states Nepal and India in the twenty-first century? This study answers this question through the secondary data interpretation
\end{abstract}

observed in practices of military diplomacy employed between two states and their analyses by linking to the concept of soft power thematically in qualitative style. For this, Indian unofficial blockade imposed upon Nepal and Kalapani-Lipulekh-Limpiyadhura territorial border dispute started since 2019 are two major issues of this study. The study finds the issue of economic blockade and border row that happened during 2015-2021 as the main factor which shifted the NepalIndia ties into a new paradigm, expanded the role of military diplomacy in new heights and developed a new public trust upon the military performance as a soft power in diplomatic realm. To present this idea, the paper explains contextual and conceptual operations of military diplomacy, soft-power and realism in the first part, detailed account of practice of military diplomacy in the middle part, and conclusion in the last part.

Keywords: military diplomacy, soft power, unofficial blockade, Kalapani-LipulekhLimpiyadhura

\section{Introduction}

The beginning of maiden visit of Nepal Army (NA) chief the then General Rajendra Chhetri to receive the title of honorary General of India on February 1, 2016 in invitation of IA 
was great gamble in the history of military diplomacy; because of Nepal-India rocky relationship developed since 2015 (Thapa, 2016; Anand, 2016). Fortunately, it became the milestone to upgrade the Nepal-India military diplomacy into new era creating a successful history in two countries' relations. Because, the "[t]he blockade was still on when he departure for India but miraculously lifted just a day before this arrival back in Kathmandu" (Thapa, 2016). It was succeeded through a large-scale package of soft power diplomatic actions of the then CoAS of Nepal in cooperation of the Indian Army (IA). It was a joint effort of two countries' military chiefs within their military diplomacy with a close connection and facilitation of concerned political leaders of Nepal and India. In this course, Chhetri had worked before the starting of visiting through his military missionary. During the visit, he met top Indian political leaders beyond his military counterparts. He had got this success with a strong positive cooperation of IA. Finally, the effort persuaded the political leaders to finish the blockade and contribute to further cement the bonds of Nepal-India friendship in a normalized and positive way (Anand, 2016).

The official visit of CoAS of Nepal to India was chockful of serious controversy in homeland. On the other hand, the challenge of resulting to halt the unofficial blockade of India was extremely not easy. Because, in political level the then Minister of Commerce and Industry Nirmala Sitharaman and national security advisor Ajit Doval were not in favor of lifting blockade. However, the then IA chief General Dalbir Singh Suhag who was in opposition of blockade, himself convinced Prime Minister (PM) Narendra Modi to lift the blockade (Chhetri, 2016; Pokharel, 2020). It was an influencing example of implementing military diplomacy that produced an immediate result in favor of Nepal. Further, it was soft power strategy effectively practiced in diplomatic war to response India against the use of a kind of realist weapon economic blockade. Soft power is achieving objectives through persuasion and argument rather than use of weapon and economic threat (Nye, 2004). Nepal got success to deploy its soft power diplomacy in a central role of Nepal Army (NA) with a powerful south neighbor. NA has played the role in a prior informed consent of President, Prime Minister(PM), Defense Minister (DM) and Finance Minister (Chhetri, 2016) where the NA has got strong and constructive coordination as well as support of IA (Chhetri, 2016; Thapa, 2016; Pokharel, 2020).

Military diplomacy came in the practice of Nepal-India relations in a new model resetting the strained ties; which produced a conducive environment to roll the red carpet to PM of Nepal KP Oli; who paid his official visit to India on February 19, 2016 (Chhetri, 2016; Jaiswal, 2016). It was an important move for Nepal. However, the revived smooth relationship between two immediate countries could not last long. Another dispute related to Kalapani-Lipulekh-Limpiyadhura border issue came in pole position in 2019; which is yet to be solved. Although, the boarder issue was seeded before the economic blockade, from the joint statement release of Chinese President Xi Jinping and Modi on LipulekhPass in May 2015 referring it as bilateral Indo-China trade route (Dahal, 2020; Jaiswal, 2016). It was opposed by Nepal and termed as a threat to state's sovereignty and territorial integrity. The then Foreign Minister (FM) Pradip Kumar Gyawali's statement has raised concern with the Indo-China discussion in absence of Nepal about the area of Nepalese 
territory (Rajan, 2019).

Unfortunately, India did two more political actions subsequently after 2015 related to Kalapani-Lipulekh-Limpiyadhura border issue:

i) Home Minister (HM) of India published a new updated political map of India including Nepal's Kalapani-LipulekhLimpiyadhura area in November 2, 2019 (MoFA, 2020; Nayak, 2020; Rajan, 2019), and

ii) Subsequently, Indian DM Rajnath Singh inaugurated an 80-km-long road in Uttarakhand connecting the Lipulekhpass of Darchula on May 8, 2020 (Peri, 2020). It is located at 17,000 feet on the India-Nepal-China tri-junction (Bhalla, 2021; The Times, 2020).

Nepal again reiterated that the actions of India were one-sided, threatening Nepal's territorial integrity and sovereignty and gave immediate responses to both of these actions. Nepal delivered the statement of objection over the new Indian Map claiming the Kalapani area of Nepal's Darchula district and showing commitment to protect country's territory anyhow (Nayak, 2020), requested to correct the action and to seek the solution through dialogue. However, India did not correct the map rather inaugurated a new road in the disputed area. Therefore, Nepal protested against inauguration of new road; claiming the pass-through Nepali territory. Days later, Nepal too released its new map including Kalapani-Lipulekh-Limbpiyadhura territory in Nepal's new map (Dahal, 2020, Government unveils, 2020). Still the dispute is unsolved between two countries.

These actions of two neighboring countries led the dispute into complicated juncture.
High-level political visits and dialogues are stopped now. Both countries' silent position shows the practice of quiet diplomacy in political level. Military diplomacy is operating its actions continue to connect and facilitate relations as a soft power instrument. So, the new expectations upon military diplomacy are increasing in contemporary Nepal-India foreign relations.

\section{Realism, Soft Power and Military Diplomacy}

Generally, the word 'military' reveals hard power with deployment of weapon. Traditionally, such understating and role of military was common in International Relations (IR). Typically, hard power uses military threat, economic reward and also obliges the addressee to consider the interests in terms of cost and benefit calculation (Gray, 2011). The hard power concept is under an old theory 'realism' where states are the major actors in International Relations (IR). They like to practice their monopolies in an anarchical international society through military violent operations (Beer \& Hariman, 2018). It is justified according to the ethics of responsibility and survival of state rather than morality.

However, international system is dynamic and power relationship is changeable over time (Pyle, 2011). So, the international world order of the twenty-first century has a drastic change in comparison to the twentieth century. It has also shifted the understanding of realism into post-realism. The post-realism understands more than military actions with the coexistence of both hard and soft power with verities of modalities like military, political, economic, communication, rhetoric and so on (Beer and Hriman, 2018). Thus, the changing concept of realism towards 
post-realism attempts to redefine the role of military into new modality. On the other hand, military diplomacy principles define the role of military under the soft power diplomacy which is rising globally.

Soft power refers to the persuasive modality in spite of coercive threat and action (Nye, 2004) which is a capacity to convince others by cooption to share the same values (Gray, 2011). It helps to shape other's actions, exchange of understandings, values, and influence contextually and necessity (Muniruzzana, 2020). Thus, military diplomacy is a soft power diplomacy which has more diverse functions in contemporary days. In the beginning days of nineteenth century, it had exclusively focused on performance of gathering and analyzing armed force information of foreign states to evaluate the military threats and interventions (Pajtinka, 2016).

In comparison to the beginning of its modern exercise in nineteenth century, military diplomacy has extended many fundamental new working roles. Some notable extended working areas under the new modality are promotion of cooperation and communication of defense, exchange of military authorities, representatives' official visits, business contract supports on military arms and equipment, exchange of education and training, humanitarian and disaster relief assistance. Besides these, the broader definition of military diplomacy comprises almost every external relation related to military activities within its scope (Jaishankar, 2016). So broadly military diplomacy is, “... a set of activities carried out mainly by the representatives of the state defense bodies, as well as of other state institutions, aimed at pursuing the foreign policy interests of the state ...." (Pajtinka, 2016, p. 184).

\section{Nepal-India Bilateral Relations and Military Diplomacy}

The formal military diplomacy between Nepal and India began only after the then IA General Kodandera Madappa Cariappa's goodwill visit to Nepal in 1950; although, its history, as an alternative diplomacy has an older than Nepal-India friendly relationship began after Treaty of Peace and Friendship of 1950 (Asia Institute for Diplomacy and International Affairs [AIDIA], 2021; Sood, 2020). It is proved by the antiquated history of Sugauli Treaty, signed between Nepal and East India Company in 1816, which allowed the British to recruit Gorkhas in British Army (Chhetry, 2021). Tripartite Agreement among Nepal, India and United Kingdom took place at the time of Indian independence in 1947 was another foundation to boost Nepal-India military diplomacy. The agreement was regarding to the rights of Gorkha soldiers. When, Nepal had denied to assent Pakistan's claim for Gorkha soldiers in Pakistan military and China's request for Gorkha soldiers to serve in People's Liberation Army after 1962 (Chauhan, 2021).

Nepal's relationship with India has a unique diplomatic engagement in terms of maiden foreign visit of PM as a symbol of close neighboring country relations. PM of Nepal begins his/her first foreign official visit from New Delhi. Similar to this, NA chiefs too make New Delhi as their first international destination after taking command of the defense force (Nepal Army, 2021). Beyond the NA chief's visit there are plenty of other exemplary actions, which are exchanged between two military institutions; such as humanitarian cooperation, joint training, educational exchange, military weapon market management and so on. Among them, the conferring honorary rank of General to 
each other and joint training are significant as well as current regular programs briefly narrated as below:

\section{Conferring Honorary General Rank}

Tradition of conferring title of an honorary General to each other between two military institution of Nepal and India was started since 1965 (Chauhan, 2021). It is not only a unique, regular and customary but also a mark of the closest and special relationship between two countries (Anand, 2016; Army Chief, 2018; Bhattarai, 2020; Nepal Army, 2018). It was historically released from the first goodwill visit of Cariappa to Nepal in 1950 (Basnet, 2020; Chauhan, 2021). Two defense institutions NA and IA use to confer honorary rank General to each of the CoAS of institutions. For this purpose, NA invites Indian CoAS for an official visit to Nepal, similarly, IA officially invites Nepalese CoAS for official visit to India. The state head of respective countries confers the title.

Since the beginning of tradition; 16 Army chiefs of Nepal have paid their official visit to India and 21 Army chiefs of India have paid their visit to Nepal. This visit supports to strengthen the specific bonding for overall ties including defense and security (Basnet, 2020; Chauhan, 2021). The then NA's General Chhetri's visit with a successful diplomatic outcome glorifies the value of this unique tie in the long course of visit history. In normal observation, the visit was just a continuity of an established tradition; however, it was a diplomatic, courageous and political.

Chhetri's visit was highly criticized in public and political realm of Nepal which shows the time was not appropriate to visit India (Nepal's Army, 2016; Thapa, 2016). Because, it was during the severely ruined diplomatic relationship between two countries after September 23, 2015 due to the economic blockade imposed to Nepal by India. Surprisingly, this visit got a historic success to end the blockade. So, it was a kind of diplomatic visit with the political value taking a political nod from the then Nepalese high level political authorities.

\section{Joint Training}

This joint military action is an ideal platform for experience sharing to enhance defense cooperation, to extend mutuality and friendship to each other. Nepal and India have been conducting a battalionlevel training - Surya Kiran military exercise every year alternating between two countries to strengthen the military capacity (Parameswarn, 2016; Thapa, 2016). It was started since 2011 at Vairangate Mizoram of India as agreement Seventh Nepal-India Bilateral Consultative Group on Security (Adhikari \& Thapa, 2020; Bansal, 2014).

Military chiefs of the two countries do observe the joint exercise. For instance, the then CoAS of Nepal SJB Rana and the then Indian CoAS Bikram Singh had jointly observed the joint group training exercise Surya Kiran-VI in Saljhandi, Rupandehi of Nepal on March 14, 2014 (Nepali Army, 2014). Similarly, the then CoAS of IA Suhag had witnessed the concluding ceremony of tenth 'Surya Kiran' military exercise conducted in Nepal (Thapa, 2016). Both Nepalese and Indian militaries participate in training during the exercise. In terms of troop participation, it is the largest exercise series for India in comparison to the exercises with other countries (Parameswarn, 2016). It is a hallmark to improve bilateral friendship. 


\section{Paradigm Shift In Bilateral Ties and Energized Role of Military Diplomacy}

Four critical diplomatic issues, produced in Nepal-India relationship during 2015 to 2021 have shifted the paradigm of bilateral ties in a new mode. The first issue is unofficial blockade of India to Nepal in 2015 (Aryal, 2019; Pant, 2018; Thapa, 2016). The second issue is India's new political map, released in November 2, 2019 including the Nepal's territory Kalapani-Lipulekh-Limpiyadhura. Third issue is India's action of 80-km-long new road inauguration through Nepalese territory Lipulek-Pass area in the name of cultural link road to Kailash-Mansarovar pilgrimage in May 8, 2020 (Sagar, 2020). Fourth, is Nepal's action of map publication as reaction to India's encroachment, depicting the Kalapani-Lipulekh-Limpiyadhura territory in Nepal in May 20, 2020.

These all-sequential developments of critical events created many problems between two neighboring countries. Both countries changed their diplomatic behaviors. Military institutions played a creative role as soft power diplomat. It was an important turning point as a new paradigm shift in Nepal-India relations (Bhattarai, 2020; Government Unveils, 2020; MoFA, 2020; Pradhan \& Giri, 2020; Nepal-India, 2020). Signifying this development AIDIA (2021) articulates that a sever paradigm shift in bilateral NepalIndia ties was emerged after Nepal's reaction against the economic blockade of India in 2015 and new political map release including Nepalese territory. Nepal accused India as actor of economic blockade, though, India never officially accepted it as blockade. The then Indian FM Susma Swaraj had claimed with her counterpart the then Nepalese Minister of Foreign Affairs Mahendra Bahadur Pandey in Delhi, “... the allegation that India had imposed a blockade was "totally false"” (India News, 2016).

Successful role of two countries' Army chiefs to end the economic blockade (September 23, 2015 to February 5, 2016) and diplomatic participation in tension of Kalapani-LipulekhLimbpiyathura boarder row ongoing from 2019 has elevated the military diplomacy in a new advancement. On the other hand, the COAS of India Manoj Mukund Naravane's controversial statement about the issue of Kalapani border area (Pokharel, 2020) and the then COAS of Nepal Purna Chandar Thapa's visit to Kalapani area in June 2020 as the response to Naravane (Bhattcherjee, 2020) were also a diplomatic practice. These both circumstances advances the role of military diplomacy. Today, the military diplomacy between two countries has got a place in forefront of political sphere of Nepal-India relations.

Its value has been further justified from the more elaboration of joint venture of Chhetri and Singh. Because, their joint effort of landing the cold relationships between two countries through the soft military diplomatic practice during the Chhetri's maiden visit is remarkable. Chhetri's India visit was just to receive honorary General; however, his diplomatic effort in cooperation of Singh had miraculously resulted diplomatic solution. It was a hardly ever-expected consequence in the diplomatic realm; however, it got truth in history of Nepal-India ties. Before this, visit of military chiefs to receive honorary General were just a customary practice (Gurung, 2009). It has placed new vale and expectation in order to boost relationship of two countries in present days.

Indian COAS Naravane's visit gives an additional illustration of new expectations. 
The visit to Nepal was in November, 2020 to receive honorary rank of NA General. It was the first high-level visit from Delhi to Kathmandu after the border dispute originated from inauguration of road connecting to the Lipulekh-Pass on May 8, 2019. India has decided to send the CoAS to Nepal to reset the relationships when there was an expectation to have a significant diplomatic overturn with Nepal scheduling the talk with top-level civilians (Army Chief, 2020, Nepal-India, 2020). In Nepal, Naravane's visit was also marked as more meaningful than other regular visits. Since there was long gap of bilateral dialogue in political level besides some formal telephone conversations between two nations' PMs, some regular meeting and activities in the level of embassies in Kathamandu and Delhi (Pokharel, 2020).

There was only a limited public role of NA in national politics of Nepal. It was seldom discussed about the NA's diplomatic effort in national Medias despite narrative news of COAS visits (Housden, 2013). But the current situation is converse. The official visits and action of either NA chief or IA chief to each other countries' equally occupy the national media of Nepal as well as of India. For instance, Kallol Bhattacherjee (2020) in a popular big media of India started from 1878 The Hindu, wrote showing the deep concern regarding to the Nepalese the then COAS Thapa's visit to Kalapani boarder area; where, he has expressed the India's diplomatic disagreement over Nepalese army's visit. This visit was symbolically important regarding to disputed area. There was further claimed that the visit of Thapa was because of presser of the then Defense Minister.
Similarly, Nepalese COAS Prabhu Ram Sharma's recent visit to India in November 2021 was also supposedly meant to revive current Nepal-India relations in India (Bhalla, 2021; Nepal Army, 2021). NepalIndia, 2020;). The same visit of Sharma was viewed in a popular national daily of Nepal The Kathmandu Post, as not only a mere continuation of symbolic tradition, but, as an opportunity to seize a constructive engagement to create a conducive environment for addressing bilateral conflicting issues (Poudyal, 2021). Thus, the establishment of military diplomacy in a pivotal position of Nepal-India relations after 2015 has further helped shift the diplomatic dimension. The newly developed situation has produced two new factors in in diplomatic practice two countries, such as increased trust, joint effort and new expectations.

\section{Increased Trust to Military Diplomacy}

In 2016, the then CoAS of Nepal, Chhetri's visit started in a tense state of affairs (Thapa, 2016), but, it established the most successful case story of military diplomacy having a valued consequence for state. It proved the worth of soft power in diplomacy and dramatically changed the public worldview over the military as well as military diplomacy. The changed worldview established new level of trust. It is particularly after the end of Indian unofficial blockade in 2015-2016 through the crucial but secretive role of Armies of two South Asian nations (Chhetri, 2016).

It diversified the significance of military diplomacy in Nepal-India foreign relations founding a new label of civil trust and expectation, which has been currently reported during the official visit of Sharma reminding that the military's role had ended 
the Indian blockade of 2015 (Annapurna Times, 2078 BS). Four-month long blockade was undeclared but terrible, it had resulted worst humanitarian crisis in Nepal (NepalIndia, 2018). Thus, NA and its diplomatic role, in a critical and most difficult situation, not only solved the problems but also justified the value of exchanging honorary rank of General between two immediate neighboring countries. Since then, the exchange of customary visit of COASs has received new gravity.

It has also shifted the paradigm of looking and analyzing the role of CoAS of Nepal and India in diplomacy with a minute observation diplomatically and politically. Previously, it was just a ceremonial and regular visit. Now, there is an expectation of military leaderships' role to resolve the Kalapani dispute as the role played significantly to lift out the unofficial blockade during 2015-2016 (Pokharel, 2020). Because, there is full stop of active and fruitful communication between in political and diplomatic levels.

Such increasing role of military diplomacy has been revealed in many writings. Some exemplarily writings are, "[i]t was interesting to note that the civilian governments took resources to military dialogue to recover their serious bilateral deadlocks" (Subedi, 2020); or, militaries had played role of conciliating and uniting during the collided political realm of two countries (Bhattarai, 2020; Thapa, 2016). “...[M]ilitary diplomacy has been active to open communication channel to get their bilateral relations back-to-back." (Subedi, 2020)

\section{Joint Effort With Successful Diplomatic Cooperation for Solution}

The maiden visit of Chhetri aiming to diplomatic solution with a powerful neighboring country was really a risky and overloaded. There were many dilemmas in the course of conforming visit, although, Chhetri perfectly converted it into success. But, the success was not only an individual effort of him, it was a joint effort of two military institutions with successful cooperation in political level. Singh led IA was very respective and cooperative to the two senior Nepali officers as envoy of Chhetri in their mission in Delhi. Singh has expressed his dissatisfaction with the blockade in discussions with Indian leaders. It had created a favorable environment for Chhettri to work ahead. Shing continued his cooperation to Chheri's effort. Chhetri was continuing discussion with his counterparts on various security challenges faced by two countries and the implications for the two allies if the blockade was not lifted (Pokharel, 2020).

The effort of Chhetri working to end the blockade is found quiet but a systematic and diplomatic which he had started before the beginning of his official visit. He has worked through his military emissary in the leadership of Himalaya Thapa in Delhi in order to apprise and persuade depicting Nepal's dire situation to their counter parts as well as political leaders (Pokharel, 2020; Thapa, 2016). The visit was such a planned and diplomatic that after the joint discussion between IA and envoy of Chhetri only IA had dispatched the official invitation to NA General (Pokharel, 2020).

IA facilitated all the persuasive dialogues of Chhetri with military high-level officers and with political leaders. It displays the IA's sincerity as beset relationship with NA. It is also, claimed that Singh's goodwill management ruined the distrust to regain 
the Nepal-India smooth bilateral relations (Thapa, 2016). The events show that the Chhetri's meetings with top political leaders brought the solution of the problem. Talking was in the foundation of political permission of Nepal. Because, Chhetri had initiated the discussions taking the political consent of the PM Oli and DM Bhim Rawal of Nepal. In India, Chhetri had met the then Indian Defense Minister, Home Minister, National Security Advisor and others" (Pokharel, 2020).

\section{New expectation through military diplomacy}

Still, the relationship of Nepal-India is not in smooth and normal after 2019. In this context, there is a new expectation of a meaningful role of military diplomacy to regain a smooth relationships. There were some reflections exposed in public level regarding to the expected role of military diplomacy in NepalIndia current bad relationship's improvement.

\section{Icebreaker}

NA invited IA General Naravane for an official visit to Nepal when two countries' relationship was already in crisis due to the boarder row. The visit of Naravane on November 2020 became the first high-level official visit after the eruption of Kalapani border area dispute after November 2019. In this sense, the visit was taken as an icebreaker of the frozen relationship from the beginning of 2020 in political level. His visit had aimed to reset the bilateral ties produced after bitter boarder row (Nepal-Inda, 2020). It was expected as an extra useful diplomatic tool as icebreaker before the problem to produce a positive environment for the diplomatic channels to untangle the chaos (Chhetry, 2021).

\section{Role of facilitation}

Both CoAS of Nepal and India after 2019 are observed as facilitating and connecting factor for ruined ongoing relationship. The Naravane's visit was the first opportunity of India to talk with Nepali political leaders about Kalapani-Lipulekh-Limbpiyadhura. Because, after the beginning of this tension it was the first meeting of Nepalese PM with high-level Indian officer which was meeting with Naravane (Peri \& Bhatacherjee, 2020).

Similarly, NA CoAS Sharma's visit in 2021 to India has also been analyzed as another means to understand the Kathmandu's opinion on boarder issue for Delhi. Eventually, it is true that current socio-political sphere has a kind of expectation to military diplomacy as connecting and facilitating factor between two countries during the strained relationship position. This fact is claimed in India as, "[i]t is indeed high time for India to use the collaborative strength of the Indian Military Diplomacy and re-strengthen the mutual trust and cooperation with Nepal" (Chhetry, 2021, p. 12).

\section{Opportunity to revive trust}

Once the cold relationship began in 2015, It was normalized by 2016. But, again, two countries produced a new controversy of Kalapani border area territory since 2019. Actually, there are no high level visits between Nepal-India besides the telephone conversation between Oli and Modi on April 10, 2020. When, they had talked about the problem of Covid-19. As Nepal's claim, Nepal has asked India many times sit together of foreign secretary meeting to resolve the current crisis, however, India is reluctant and not paying attention to close neighbor. This is found against the India's own principle 
'neighborhood first' (Saxena, 2020). Both countries are employing just only a silent diplomacy regarding to the problems that has only shown the ties improved in later year.

During the period, IA chief Naravane visited Nepal in November, 2020s when the NepalIndia ties were already crumbled-down. However, it was analyzed as a positive symbol to turn away from deepening refutation of New Delhi and Kathmandu in their bilateral relations (Rej, 2020). The NA chief Sharma's recent visit in this moment 2021 was also taken as the revival signal of friendship relations (Bhalla, 2021).Just as the hypothesis of visits' result assumed in public and well as political sphere, the political level visits and bilateral dialogues got progress between two countries after Naravane's visit to Nepal. India's foreign secretary to Foreign Minister of Nepal's visits has been concluded to each other; however, the Kalapani boarder tension is not resolved yet. At least, a series of visits by high-ranking officials of Delhi to Kathmandu is found in progress (Former Nepali, 2021).

\section{Conclusion}

The study shows that the military diplomacy has currently been the most popular in the centuries old diplomatic history of Nepal and India. Both countries have the weakest chance of deploying gunboat diplomacy because of their geopolitical position, socio-cultural connectivity, vast difference in power rivalry and existing world order of twenty first century. However, military diplomacy has increasingly occupied wider space in their relations and has been the most effective soft power instrument to convey the message of an alive relationship, to bond the ties stronger, to solve the problems and to reset the strained relationship into a normalized position.
Continued active military diplomacy of both countries during the unofficial blockade of India to Nepal and ongoing KalapaniLipulekh-Limpiyadhura territorial dispute has verified it as a favorable and comfortable persuasive approach upon stressed relations. Because, both party has applied it equally in a constructive way to look for the further solution; when, the diplomacy in a political level has setback. The success case of military diplomacy effort in leadership of Chhetri and Singh to break out the deadlock of Nepal-India bonds caused by unofficial blockade shows its bright possibility of an effective continuity, in coming days as well. Likewise, continuity of diplomatic efforts through the Naravane's visit to Nepal and Sharma's visit to India and expectations raised in public realm during the crumbled bilateral relationship between two nations erupted after November 2019 justify the burning significance of military diplomacy.

Because, the journey of diplomatic relationship between two neighboring countries of South Asia; Nepal and India is a never-ending project historically started before Treaty of Sugauli and systematically tied through Treaty of Peace and Friendship of 1950. Wherein, despite a lots of quite similarities to each other both nations have many distrust and doubts in their relationship; nevertheless, there is no alternate to continue the relationship with full respect of sovereignty and national integrity to each other. In this long journey, the practice of military diplomacys as a dynamic soft power instrument has succeeded to place its position in a new turning point as an necessary, active and powerful diplomatic tool from the beginning of this century. 


\section{Reference}

Adhikari, N. \& Thapa, M. (2020). Enter to new realist era? Major trends of Nepali diplomacy in federal republic era. Journal of APF Command and Staff College, 3(1) 137-151

Anand, R. (2016, February 16). President of India confers Honorary India Army General rank to Nepalese Army chief. Sainiksamachar. http://www.sainiksamachar.nic.in/ englisharchives/2016/feb16-16/h3.htm

Annapurna Times. (2078 BS, Kartik 22). Pradhansenapapati Sharma aafnai kasa jahaj chadhera kina jadaichhan Bharat? [Why is General Sharma going to India aboard his own Casa plane?]. Annapurna Times. https://annapurnatimes.com/ archives $/ 44266$ ? fbclid=Iw AR 1 pV 1 WxqVTby 2 -rHTzmnwfRL-KqbC_ SXTg3NgKxPRWutXJcFB8Xwtgwkb4

Army chief (2018, July 12). General Bipin Rawat to visit Nepal for defense cooperation. The Economic Times. https:/ economictimes.indiatimes.com/news/ defence/army-chief-general-bipin-rawatto-visit-nepal-for-defence-cooperation/ articleshow $/ 57718833$.cms? from $=\mathrm{mdr}$

Army chief. (2020, October 25). Gen MM Naravane scheduled to visit Nepal from November 4-6 with an aim to reset ties. The Economic Times. https://economictimes. indiatimes.com/news/defence/army-chiefgen-mm-naravane-scheduled-to-visitnepal-from-nov-4-6-with-an-aim-to-resetties/articleshow $/ 78858686 . \mathrm{cms}$ ?from $=\mathrm{mdr}$

Aryal, J. (2019). The nature and impacts of 2015 Indian unofficial blockade in Nepal. [Unpublished Thesis]. Norway University of Life Science.

Bansal, M. (2014, September 5). Indo-Nepal join military exercise Surya Kiran-VII concluded at Pithoragarh. Jagran Josh. https://www. jagranjosh.com/current-affairs/indonepaljoint-military-exercise-surya-kiranviiconcluded-at-pithoragarh-1409912240-1

Basnet, G. (2020, November 3). Honorary title of Army chief: A historic display of special bonding between Nepal and India. Khaburhub.com. https://english.khabarhub. com/2020/03/139160/

Bhalla, A. (2021, November 8). Nepal Army chief to be conferred with honoury 'General' ran of Indian Army, meet PM Modi during 4-day vist. India Today. https://www. indiatoday.in/india/story/nepal-army-chiefindia-visit-pm-modi-general-rank-indianarmy-1874436-2021-11-08/

Bhattacherjee, K. (2020, June 19). Controversy stalks Nepal Army chief's visit to Indian border. The Hindu. https://www.thehindu. $\mathrm{com} /$ news/national/controversy-stalksnepal-army-chiefs-visit-to-india-border/ article31872467.ece

Bhattarai, G. (2020). Assessing Nepal's military diplomacy: Neighborhood and beyond. Unity Journal, (3), 48-56.

Beer, F. A. \& Hariman, R. (2018). Realism, Post-Realism and ISIS. In D. Orsi, J. R. Avgustin \& M. Nurnus (eds.), Realism in practice an appraisal (pp. 16-28) Bristol: E-international Relations Publishing.

Chauhan, G. S. (2021, June 4). Defense relations between India and Nepal. Financial Express. https://www.financialexpress.com/ defence/defence-relations-between-indiaand-nepal/2265138/

Chhetri, R. (2016, February 19). Camaraderie between Nepal Army \& Indian Army ended blockade, not politicians. Southasia. https://www.southasia.com.au/2016/02/19/ camaraderie-between-nepal-army-indianarmy-ended-blockade-not-politicians/ 
Chhetry, A. (2021) Decoding Indo-Nepal relations from the Prism of Indian Military diplomacy. Centre for Land Warfare Studies (claws): Issue Brief, No 300. https://www. claws.in/publication/decoding-indonepal-relations-from-the-prism-of-indianmilitary-diplomacy/

Dahal, S. (2020). Relations between India and Nepal in Covid-19 situation. Journal of Historical Archaeology \& Anthropological Science, 5(5) 175-181 DOI: 10.15406/ jhaas.2020.05.00232

Former Nepali Army chiefs' presence at Indian Army military conclave highlights fraternal ties.(2021, September6). South Asia Monitor. https:/www.southasiamonitor.org/region/ former-nepali-army-chiefs-presenceindian-army-military-conclave-highlightfraternal-ties?utm_source=JioNews\&utm medium $=$ referral\&utm campaign $=$ JioNews

Gurung conferred with Indian Army Gen rank. (2009). The New India Express. https:// www.newindianexpress.com/nation/2009/ dec/15/gurung-conferred-with-indianarmy-gen-rank-112983.html

Government unveils new political map including Kalapani, Lipulekh and Limpiyadhura inside Nepal borders. (2020, May 20). The Kathmandu Post. https://kathmandupost. com/national/2020/05/20/governmentunveils-new-political-map-includingkalapani-lipulekh-and-limpiyadhura-insidenepal-borders

Gray, C. S. (2011). Hard power and soft power: The utility of military force as an instrument of policy in the 21st century. Carlisle, Pa: Strategic Studies Institute, U.S. Army War College.

Housden, O. (2013, October 4). The deft politicking of Nepal's Army. The Diplomat. https:/thediplomat.com/2013/10/the-deft- politicking-of-nepals-army/

AIDIA (2020). India-Nepal relations: The way ahead. http://aidiaasia.org/webinar/indianepal-relations-the-way-ahead

Indian Army Invites Former Chiefs of Nepal Army to New Delhi. (2021, September 2). My Republica. https://myrepublica. nagariknetwork.com/news/indian-armyinvites-former-chiefs-of-nepal-army-tonew-delhi/

India News. (2016). False allegations of blocking trade at Nepal border, says India. Hindustan Times. https://www.hindustantimes. com/india/false-allegations-of-blockingtrade-at-nepal-border-says-india/story5g4Vsa23LCR3zDBZ711gcK.html

Jaiswal, P. (2016, February 19). Significance of Prime Minister KP Oli's New Delhi visit. Institute of Peace and Conflict Studies. http://www.ipcs.org/comm_select. php?articleNo=4991

MoFA. (2020). Report on Nepal's foreign affairs (2019-2020). Kathmandu: Ministry of Foreign Affairs.

Muniruzzaman, A. N. M. (2020). Defence Diplomacy: A Powerful Tool of Statecraft. CLAWS Journal, 13(2), 6380. https://ojs.indrastra.com/index.php/ clawsjournal/article/view/19

Nayak, S. (2020). India and Nepal's Kalapani Border Dispute: An Explainer. ORF Issue Brief No. 356, https://www.orfonline. org/wp-content/uploads/2020/04/ORF IssueBrief 356 India-Nepal-Kalapani.pdf

Negi, M. (2021, September 20). India, Nepal begin joint military exercise 'Surya Kiran' in Uttarakhad's Pithoragarh. India Today. https://www.indiatoday.in/ india/story/india-nepal-joint-militaryexercise-surya-kiran-uttarakhand- 
pithoragarh-1854924-2021-09-20

Nepali Army. (2014, March 14). Exercise Surya Kiran-VI. https://www.nepalarmy.mil.np/ viewnews/141

Nepali Army. (2021, November 9). CoAS General Sharma departs for India. https://www. nepalarmy.mil.np/viewnews/471

Nepal's Army chief Rajendra Chhetri to visit India next week. (2016, January 28). The Economic Times. https://economictimes. indiatimes.com/news/politics-and-nation/ nepals-army-chief-rajendra-chettri-to-visitindia-next-week/articleshow/50760273. cms?from $=\mathrm{mdr}$

Nepal Army (2021, December 23) Chief Thapa to visit India on January 11. The Kathmandu Post. https://kathmandupost.com/ miscellaneous/2018/12/23/nepal-armychief-thapa-to-visit-india-on-january-11

Nepal-India. (2020, November 6). Nepal-India problems will be resolved through dialogue PM Oli tails Army chief Naravane. The Print. https://theprint.in/diplomacy/armychief-general-naravane-meets-nepal-pmoli-discusses-bilateral-ties/538491/

Nye, J. S. (2004). Soft power: The means of success in the world. New York: Public Affairs.

Pant, B. (2018). Socio economic impact of undeclared blocked of India on Nepal. Research Nepal Journal of Development Studies, 1 (1), 18-27. https://nmbu. brage.unit.no/nmbu-xmlui/bitstream/ handle/11250/2618546/Master\%27s\%20 Thesis_\%20May\%202019_Jhabakhar\%20 Aryal_Final.pdf? sequence $=1 \&$ isAllowed $=y$

Pajtinka, E. (2016). Military diplomacy and its present functions. Security Dimensions: International and National Studies, (20), 179-194. https://doi.org/10.24356/SD/20/9
Paudyal, S. B. (2021, November 10). In defense of military diplomacy. The Kathmandu Post.. https://kathmandupost.com/ columns/2021/11/08/in-defence-ofmilitary-diplomacy

Parameswarn, P. (2016, November 15). India, Nepal hold military exercise with terror focus. The Diplomat. https://thediplomat. com/2016/11/india-nepal-hold-militaryexercise-with-terror-focus/

Peri, D. \& Bhattacherjee, K. (2020, November 6). Army chief Naravane meets Nepal PM Oli assures further defense cooperation. The Hindu. https://www.thehindu.com/ news/national/army-chief-naravane-meetsnepal-pm-oli-assures-further-defencecooperation/article33041287.ece

Peri, D. (2020, May 8). Rajnath Singh inaugurates new road to Kailash Mansarvar. The Hindu. https://www.thehindu.com/news/national/ rajnath-singh-inaugurates-new-road-tokailash-mansarovar/article31533372.ece

Pokharel, G. (2020, October 21). Indian army chief's visit could be opportunity for Nepal to understand Delhi's view on border dispute. Onlinekhabar. https://english.onlinekhabar. com/indian-army-chiefs-visit-could-beopportunity-for-nepal-to-understand-delhisview-on-border-dispute.html

Pradhan, T. \& Giri, A. (2020, May 18). Cabinet endorses new political map that includes all territories tha Nepal claims. The Kathmandu Post. https://kathmandupost.com/ national/2020/05/18/cabinet-endorses-newpolitical-map-that-includes-all-territoriesthat-nepal-claims

Pyle, K. B. (2011). International Order and the Rise of Asia: Theory and Practice. In A. J. Telis, T. Tanner \& J. Keough (eds.), Strategic Asia 2011-12: Asia responds to its 
rising power China and India. (pp. 34-62) Washington: NBR.

Rajan, A. (2019). India-Nepal row over the update map of India. ISAS Working Paper No. 321, https://www.isas.nus.edu.sg/wp-content/ uploads/2019/12/Working-paper-IndiaNepal-Border-Amit-Ranjan-061219-JVHS.pdf

Rej, A. (2020, November 5). Indian Army chief begins Nepal visit amid modest improvement in ties. The Diplomat. https:// thediplomat.com/2020/11/indian-armychief-begins-nepal-visit-amid-modestimprovement-in-ties/

Saxena, S. (2020). India-Nepal bilateral relations. White Black Legal: The Law Journal, 2(2) 5-13 https://www.whiteblacklegal.co.in/ wp-content/uploads/2020/06/Vol-2-Issue-2Sanskriti-Saxena.pdf

Sagar, P. R. (2020, May 8). Rajnath inaugurates road that cuts Kailash-Mansarivar travel time, aids troops. The Week. https:// www.theweek.in/news/india/2020/05/08/ rajnath-inaugurates-road-that-cuts-kailashmansarovar-travel-time-aids-troops.html

Sood, R. (2020). A reset in India-Nepal relations. ISAS Working Paper No. 329, https://www.isas.nus.edu.sg/wp-content/ uploads/2020/07/329-1-1.pdf

Subedi, R. R. (2020, October 18). Can military diplomacy reset Nepal-India ties?. The Rising Nepal. https://risingnepaldaily.com/ opinion/can-military-diplomacy-resetnepal-india-ties
Thapa, C. J. (2016, November 11). Nepal-India relations in the military realm. Southasia. https:/www.southasia.com.au/2016/11/11/ nepal-india-relations-military-realm/

The Times of India. (2020, May 8). Rajnath Singh inaugurates strategically crucial road in Uttarakhand. The Times of India. http://timesofindia.indiatimes. com/articleshow/75624196.cms?utm source $=$ content ofinterest $\&$ utm medium $=$ text\&utm_campaign $=$ cppst 